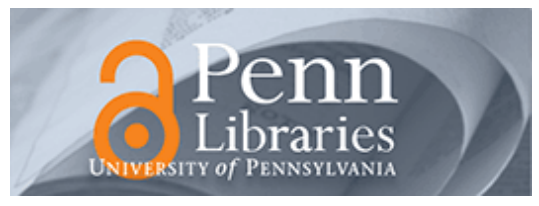

University of Pennsylvania ScholarlyCommons

$11-1998$

\title{
Top Management Pay: Impact of Overt and Covert Power
}

Harry G. Barkema

Johannes M. Pennings

University of Pennsylvania

Follow this and additional works at: https://repository.upenn.edu/mgmt_papers

Part of the Business Administration, Management, and Operations Commons

\section{Recommended Citation}

Barkema, H. G., \& Pennings, J. M. (1998). Top Management Pay: Impact of Overt and Covert Power. Organization Studies, 19 (6), 975-1003. http://dx.doi.org/10.1177/017084069801900604

This paper is posted at ScholarlyCommons. https://repository.upenn.edu/mgmt_papers/71

For more information, please contact repository@pobox.upenn.edu. 


\title{
Top Management Pay: Impact of Overt and Covert Power
}

\author{
Abstract \\ This paper examines variations in executive pay as a function of CEO power. We assume that CEOs \\ optimize their pay conditional upon their ability to shape decisions that favour their interests. Power is \\ inferred from overt manifestations such as share holdings, but also from covert sources such as a CEOs' \\ social capital. Two components of compensation are considered: base pay and bonus. While financial \\ performance, firm size, and other factors are held constant, the results show overt power as measured by \\ CEO, and CEO-family equity holdings, to have a curvilinear relationship with executive compensation. \\ Proxies of covert power include tenure, being (one of) the founder(s), and firm diversification. These \\ variables magnify or moderate the effect of equity holdings on compensation. The power effects are \\ most pronounced for the size of CEO bonus.

\section{Keywords} \\ executive compensation, shareholdings, corporate governance, power, agency theory \\ Disciplines \\ Business Administration, Management, and Operations
}




\section{TOP MANAGEMENT PAY: IMPACT of (C)OVERT POWER}

Harry Barkema, Department of Economics, Tilburg University, The Netherlands

and

Johannes M. Pennings, The Wharton School, University of Pennsylvania

October 1996new2

Do not quote. We appreciate the comments of Louis Gomez-Mejia, David Larcker, Charles O'Reilly, Louis Thomas, Henri Tosi, Mike Useem and Keith Weigelt. All errors remain our responsibility. 
TOP MANAGEMENT PAY:

IMPACT of (C)OVERT POWER

\begin{abstract}
This paper examines variations in executive compensation as a function of CEO power. We assume that a CEO's motivation to optimize his pay is conditional upon his ability to shape decisions that favor his interests. Power is inferred form overt manifestations such as share holdings, but also from covert sources such as a CEO’s social capital. Two components of compensation are considered: base pay and bonus. While financial performance, firm size, and other factors are held constant, the results show overt power as measured by CEO, and CEO-family equity holdings, to have a curvilinear relationship with executive compensation. Proxies of covert power include tenure, being (one of) the founder(s) and firm diversification. These variables magnify or moderate the effect of equity holdings on compensation. The power effects are most pronounced for the size of CEO bonus.
\end{abstract}




\title{
TOP MANAGEMENT PAY:
}

\section{IMPACT of (C)OVERT POWER}

\section{Introduction}

\author{
Despite his diminishing share of the company-some \\ 11 percent-Paley acted the omnipotent owner \\ (from In All His Glory: The Life of William S. Paley, \\ Smith, 1990)
}

It is often thought that ownership wields power, in particular if the owner is also a manager in the firm. Then the voting power from shareholdings is magnified by having a position in the firm, and the manager can use the implied power shape strategic decisions, and serve his personal goals. This paper looks at one particular application of such power: of its impact on the manager's own compensation (i.e., salary, bonus).

A key insight of the paper will be that manager-owners do not have power automatically. Rather, their power depends on their entrenchment in the firm, and on the social relationships they have built up over the years with relevant parties (e.g., directors in the firm, other managers, suppliers, etc. Embeddedness will increase their power to serve their own goals; for instance, to manipulate their salary and bonus. This paper develops this key insight further and derives various testable implications by examining data on 143 top executives in medium-sized firms in the Netherlands. 


\section{Background}

The major theoretical framework for researching CEO pay comes from economics and has been captured by the notion of agency theory. The CEO as agent performs the role of maximizing the value of the shareholders, i.e. the principal. With the separation of ownership and control, there is often the potential problem that the interests of the manager and owners do not converge, and so called agency problems ensue. For example, the stockholders might lack full oversight on the conduct and performance of the CEO. Likewise, the CEO might be motivated to make decisions that conflict with the shareholders' best interests (e.g., Jensen and Meckling, 1976). In fact, a classic idea in agency theory is that manager incentives are optimal when the manager is the full owner of the firm as this manager bears the full pecuniary consequences of his actions (Jensen and Meckling, 1976). When he is partial owner, there is the potential for divergence in interest between owners and managers. The partial ownership might confer power, and substantial leverage to manipulate compensation, although the CEO might no longer operate under conditions in which he will maximize shareholder value. The CEO might also enjoy other sources of power, including visible as well as more stealthy ones due to the recruitment and retention of lesser team members; again these sources of power might be exploited to maximize CEO, rather than shareholder interests. Within the agency literature, issues of politics and power are never considered, perhaps because such sources of aberration should be dealt with by optimizing the design of compensation plans.

Our paper explores whether such political behaviors do indeed occur, focusing on the executives' salaries and bonuses. Moreover, we explore how top managers use their holdings to manipulate their pay, and how this conspicuous form of power interacts with other surreptitious sources of power.

We should recognize that power is a concept that far exceeds the presumption of coercion, or even the imposition of will despite resistance (e.g., Blau, 1964). At most, coercion is one of many sources of power as an early paper by French and 
Raven(1959) suggested. Whenever the direction of dependence between a CEO and other power holders is shaped by an imbalance of power sources, we should define the exercise of power independently from these sources (e.g., Hickson et al., 1971). If a CEO's exercise of power is discernible from the determination of CEO compensation, any overt or covert source of power might be at stake. These sources include his ownership holdings, but also his tenure and other precedent or norm setting opportunities. All sources of power may enter into the determination of top management pay.

Some writers in agency theory have recognized that power is a relevant factor regarding top management pay. Jensen and Murphy (1990) explicitly referred to power, within and outside corporations, as a determinant of CEO pay. They argued, for example, that the public outcry over large bonuses and other financial rewards for CEOs has prevented efficient contracts that would ensure strong pay-performance relationships. Milgrom (1988) and Milgrom and Roberts (1992) suggested that executives make all kinds of effort to augment their pay, which in fact, may weaken the actual impact of corporate performance. Yet, agency theorists have not tried to open up the black box of the firm, for example, regarding how managers use their holdings to manipulate their pay. There is, however an extensive body of organizational literature that has begun to explore these issues.

\section{Management studies}

Management researchers have long been aware of the power of the CEO vis-a-vis the boards of directors. As the firm's central decision maker, the CEO represents the nerve center where many communication lines intersect. He connects many networks with non-redundant information and enjoys, therefore, an informational advantage with respect to his associates with whom he shares strategic and operational responsibility. Various writers have emphasized that CEOs play a central role in recruiting and selecting board members, determining the compensation of directors and influencing the agenda of board meetings This is because the board functions on 
information supplied by the CEO (Galbraith, 1967; Mace, 1971; Salancik and Pfeffer, 1980; Aram and Cowen, 1983; Geneen, 1984; Pierce and Zahra, 1991; Boyd, 1991, 1994).

The power of top managers may vary with who owns the firm, which in turn may affect top management pay. McEachern (1975) classified firms as 1) owner managed, those for which ownership was concentrated among its executives; 2) management controlled, for which ownership was dispersed among many shareholders; and 3) externally controlled, for which ownership was concentrated among a few individuals who did not manage the firm. Managers in externally controlled firms were expected to have little influence on their pay. Consistent with predictions, McEachern found that the cash pay (salary plus bonus) of these top managers was more strongly tied to the firm's profit and market value than for managers in the other two types of firms.

McEachern's seminal study triggered other studies comparing management controlled firms with externally controlled firms - owner managed firms remained relatively unexplored. These studies confirmed McEachern's result that pay-performance relationships for managers in externally controlled firms were stronger than in management controlled firms (see e.g., Tosi and Gomez-Mejia, 1989, 1994; Wade et al., 1990).

These studies also analyzed covert sources of CEO power, usually tenure. CEOs and existing board members were expected to develop social exchange relations over time, with the CEO being central to recruitment and compensating of new directors. Top executives with longer tenure were expected to have accumulated more power, and to be more successful in manipulating their pay. The evidence was mixed. Significant positive relationships were found between tenure and pay elements such as salary, bonus, and incidence of golden parachutes (Singh and Harianto, 1989; Hill and Phan, 1991), but also insignificant relationships were found (Finkelstein and Hambrick, 1989; O'Reilly et al., 1990), and even significant negative relationships 
(Gomez-Mejia et al., 1987; Wade et al., 1990). Still others found non-linear relations (Finkelstein and Hambrick, 1989; Gerhard and Milkovich, 1990).

For example, Finkelstein and Hambrick (1989) found no support for the positive relationship between tenure and pay predicted in their study. Further exploration revealed that total cash compensation first increased in tenure, but then decreased (an inverted U-shape) ${ }^{1}$. The authors argued that their result was consistent with 1) a power-based argument, i.e., that power accrues initially, followed by a plateauing and decline as the CEO transforms into a figurehead while potential successors emerge; or 2) a life cycle-based argument, i.e., that income and spending life style change with advancing age, and CEOs are willing to shift their compensation toward a more risky profile, away from cash compensation. Subsequent analysis showed that older executives own larger share holdings, which might fit the second interpretation.

Only a few studies analyzed the power of top managers in family owned firms (owned by the manager or his family). Allen (1981) expected these managers to be more powerful than managers in other firms, and more successful in augmenting their pay. Contrary to this prediction, he found that the direct pay (salary, bonus, deferred compensation) of CEOs was lower in family owned firms, although the aggregate pay of these CEOs (including dividends) was higher. Allen also found that family control was not only rooted in equity holdings, but also in more covert forms of power, allowing families to control the firm even if $1 \%$ or less of the shares remains within the family. Yet, Allen did not dis-entangle overt and covert power in affecting top management pay.

Finally, Finkelstein and Hambrick (1989) predicted that top management pay first increases in proportion to their holdings, and then decreases. It first increases because top managers use their power to reap money from the firm, at the expense of

${ }^{1}$ However, Finkelstein did not find this pattern for the separate elements salary and bonus. 
other shareholders. For higher levels of holdings, it becomes more attractive to leave money in the firm. In the US, personal capital gains historically have been taxed at a far lower rate than earned income. The smaller the proportional claims of others on the firm's capital gains, the more attractive it becomes for the manager to leave money in the firm. Hence, the predicted curvilinear relation (inverted U-shape).

In addition to the manager's own holdings, Finkelstein and Hambrick argued, that the holdings of other members of the CEO's family also provide him power. Moreover, family shareholders may not be as vigilant as independent directors, and the executive may have a freer hand in setting his pay. However, their evidence from a sample of firms from the leisure industry was mixed. Consistent with predictions, a curvilinear relationship (inverted U-shape) was found between CEO holdings and salary, but insignificant relationships were obtained between CEO holdings and bonus and with total cash compensation (salary + bonus). Their results involving holdings of

the family (excluding the CEO) contradicted their hypotheses. The authors attributed the lack of support to the idiosyncratic nature of their sample.

\section{THEORY AND HYPOTHESES}

These observations can now be summed up into a simple framework that is anchored in a political theory of organization. We start from the assumption that incentive systems are designed to induce a CEO to make decisions that are compatible with the interest of the residual claimants. However, CEOs often have access to sources of power that allow them to manipulate their pay at the expense of residual claimants.

We distinguish two sources of power: overt and covert. Overt power is inferred from the CEO's equity holdings, with the presumption that the greater these holdings, the better his ability to manipulate his pay. At higher levels of equity holdings, CEO inferred power is even more ostentatious, but the drive to reap more compensation declines and eventually disappears altogether, due to the diminishing wealth transfer from external equity holdings to the executive. This tendency is further bolstered by the reduced tax 
liability if funds remain in the firm compared with funds becoming part of the CEO's pay out. The implied curvilinear relationship between equity holdings and pay is consistent with recent modifications of agency based studies such as the one by Morck, Shleifer and Vishny (1992) and Finkelstein and Hambrick (1989) regarding compensation and equity holdings. However, equity holdings alone are not a sufficient condition for executive pay. It is also necessary for CEOs to have access to indigenous sources of power. That access can be inferred from their embeddedness in the upper echelons of the firm. The CEO is the primes inter pares, and particularly when he complements his financial assets in the firm with "social assets" and other out-of-sight sources, he has at least the discretion to sway compensation decisions. Since we can assume that self interest is ubiquitous, we should indeed expect him to do so.

The formal position of the CEO, in conjunction with indications of stock ownership do not exhaust the sources of power that a CEO enjoys. While formal authority as a manifestation of overt power, deriving form the position of chief financial officer matters, we should recognize that power comes also from other sources. Such sources include the ties ones has with powerful others. Managers are often endowed with coalitions of support. They have cultivated ties through their promotion and hiring decisions, followed by granting favors to those who have become part of his governance landscape. Such alliances are thus the result from having assigned people in critical positions, as well as having granted favors to them such that their support can be relied upon. It allows him to capitalize on the norm of reciprocity, which " says that we are obligated to future repayments of favors, gifts, invitations” (Pfeffer, 1992: 106). Such a norm facilitates exchange relationships among individuals across time. The favors are not necessarily sought, nor are they specified in any formal sense, but rather the favor creates a diffuse, generalized commitment (Pfeffer, 1992). The implication is that a manager who has entrenched himself in a self-compiled network of people and groups faces numerous obligations, but likewise, can count on reciprocity in matters that are important to the CEO, including his compensation package. When he is the firm's founder he commands a 
particularly advantageous position in creating a network of exchange relationships that suits his interests; he starts with a clean slate. When he succeeds the old guard, including a founder, he requires some time to undo his predecessor's governance arrangements--an undoing that improves with tenure.

Furthermore, tenure institutionalizes exchange relationships, makes them durable attributes of the governance structure. With time, the CEO is in a position to modify old practices and to set precedents for new ones which his fellow-managers begin to accept automatically. The duration on the job will likewise embellish the CEO's reputation which further solidifies his legitimacy to set precedents. Tenure promotes the standardization of new decision making protocols and the practices of the CEO's team become taken-for-granted. New additions to the board, or to the top management team are bound to conform to such practices, thus facilitating the preservation of informal control that the CEO already accumulated.

Tenure renders the CEO also increasingly as the most central person in a communication network. The persons who surround him will inevitable occupy more peripheral positions. With growing tenure, chances are that peripheral individuals are relatively recent additions to the network. They are often added at the behest of the $\underline{\text { CEO, thus reinforcing his centrality in the communication network which include his }}$ immediate associates, such as board members and senior officers. There is ample evidence that those individuals with central positions in a communication network do not only enjoy more power (e.g., Krackhard (1990), but can also affect salary and other economic returns (Pfeffer and Konrad (1991) found that individuals who had more extensive communication with peers in other institutions enjoyed higher $\underline{\text { salaries. }}$

The CEO's embeddedness renders him, therefore, constrained by commitments, side payments and other obligations. His social network obliges him. Yet, he can be expected to relish more discretion than others. As first among equals he enjoys a privileged position, especially if he can bolster this with equity holdings. Tenure and other aspects of his incumbency will further embellish his status as first among equals. In 
the course of his tenure, or endowed with the status as (one of) the founders, he enjoys surplus leverage over others who might have to ratify his decisions. Tenure, for example, will be associated with the growing size of gifts that are typically exchanged among socially connected individuals (Homans, 1961; Blau, 1974). Some CEOs, therefore, have access to a repertoire of social means to mold the outcomes of decisions that affect them personally. In short, such executives will subvert the potentially confining embeddedness, and exact surplus rents.

The obligations that are manifest in a network of social relationships are confounded by the control of resources that the actors command. Among the most salient resources are those that revolve around information and knowledge. Tenure in its own right will already confer such control because with time, the CEO learns and acquires an informational benefit vis a vis others. When he manages a strategically diversified firm he enjoys the potential of even greater information compactedness that he can readily bring into his performance-compensation condition. The implication is that under complex, strategically diverse conditions, the CEO can wield more informal power. In contrast, in single business firms, for example a productmarket that is confined to a single industry category, information asymmetries are much less likely to surface as such firms can be assumed to be more "transparent."

It is, therefore, argued that CEO compensation correspondingly reflects the joint effects of his overt and covert sources of power. It is the bringing together of this subtle process of covert with overt power, i.e., equity holdings, that sets this paper apart from the recent contributions in financial economics regarding agency and equity holdings.

\section{Salary and Bonus}

We test a number of hypotheses (separately for salary and bonus ) that are based on this framework. Salary and bonuses seem to serve different functions regarding top management pay, with bonuses more related to short-term accounting performance, and salary to job complexity of the executive (Finkelstein and Hambrick, 1989; Gerhard and Milkovich, 1990). Job complexity is usually measured in terms of firm sales and/or 
employees. Furthermore, we expect job complexity to be related to firm diversity, with job complexity being highest at intermediate levels of diversification. Therefore, we expect relatively high salaries for these executives, reflecting their relatively high marginal products. Furthermore, we expect that individual performance of these executives is difficult to measure, hence we expect fixed pay to be relatively more important as part of their pay mix. The results in Balkin and Gomez-Mejia (1990) and Gomez-Mejia (1992) are consistent with this complexity interpretation.

From the perspective of the firm, fixed and variable pay perform different functions. Salary tends to be invariant with respect to performance, while bonuses and other forms of variable pay enable the firm to closely tie compensation to individual and corporate performance. For managers, a dollar of bonus equals a dollar of salary as they both increase managerial wealth. Therefore, we expect executives to leverage in order to manipulate salaries in essentially the same fashion as they manipulate bonuses. First, the risk of the two forms of pay vary considerably. Salary is semi-fixed, meaning that a salary increase at $t_{1}$ positively affects salaries at $t_{2}, t_{3}$, etc. Bonuses are more volatile. For example, bonuses often depend on firm annual or quarterly performance, that in turn hinges on many factors beyond an executive's control, including business cycles, competitors' conduct, environmental jolts, as well as by the members of his management team. Therefore, all things being equal, risk averse executives would favor salary over bonuses discernible.

Second, it is well known that salaries increase at more or less fixed proportions with increasing hierarchical levels (Simon, 1957; Mahoney, 1979). The cost of increasing top management salary for the firm, and hence for the executive as (partial) owner, may be magnified, since increasing his own salary generates a concomitant upward pressure on lower level salaries. The net effect of these two factors may be positive or negative. That is, it is an empirical matter whether salary is more amenable or susceptible to executive manipulation than are bonuses. On balance, however, analogous to our interpretation on bonuses, we expect that top executives use their equity holdings and family holdings to similarly manipulate their salaries. 


\section{Hypotheses}

We expect that executives will leverage their share holdings to circumvent the impact of performance on compensation., i.e., they will use their holdings to "manage" the payperformance connection.

In practice, compensation committees seldom cast their votes in proportion to their members' equity holdings. The top executive may not even be a member of the compensation committee, and in publicly held firms he is barred from joining them. Equity holdings in itself do not seem a sufficient condition for influencing pay. Rather, we expect the process to be more subtle, where the actual (as opposed to potential) power from share holdings is contingent on CEO covert sources of power, that is, on his "social capital" (Tosi and Gomez-Mejia, 1989; Wade et al., 1990). Such capital is anchored in the social networks that executives have built around themselves (Burt, 1992). A CEO who has assembled a set of contacts is endowed with information which confer what Burt (1992) calls "structural autonomy". These contacts, both within and outside the firm, and the superior information that CEOs derive from these contacts, can be instrumental for the shaping of his pay mix, and, in particular, for manipulating the size of his bonus. Such social capital, as indicated by interlocking directorates, and "ties" with firms having golden parachutes has shown to be a key factor in a firm's propensity to adopt golden parachutes (Davis, 1991).

On average, executives with share holdings are likely have some covert power. Thus, we expect a CEO with share holdings to manipulate his bonus and salary. For reasons mentioned earlier, the relationship is curvilinear. This prediction is identical to Finkelstein and Hambrick (1989), who find no support for their prediction, which is attributed to the idiosyncrasies of their sample from the leisure industry. This study will test the hypothesis on multiple industry data. 
$\mathrm{H}_{1.1}$ : Bonus and salary have a curvilinear relationship (inverted U-shape) with CEO equity holdings.

Executives may not only leverage their equity holdings, but might also act so on the basis of their family holdings. In most societies, relationships among relatives are governed by strong reciprocity norms. Strong social exchange relationships (Homans, 1961; Blau, 1964) may exist between the executive and his relatives, where an executive exchanges support, affection and respect for continued tenure. ${ }^{2}$ In fact, social exchange covenants between family members may be more important than virtually any other exchange relation in society. Family holdings and family controlled firms are among the ones that appear immune to the market for corporate control (e.g., Davis and Stout, 1992), the implication being that such firms have a more discretionary governance.

However, Finkelstein and Hambrick (1989) did not find support for their prediction that an executive's bonus has a curvilinear relationship (inverted U-shape) with family holdings (excluding that of the executive), which they attribute to the idiosyncrasies of the sample. An alternative, plausible explanation is that family holdings will likely correlate with CEO holdings (because children, grandchildren, etc., of the founder share the heritage). Suppose executives do indeed serve the interests of themselves and their family, rather than focusing myopically on their own interest, and that the relationship between bonus and share holdings is indeed non-linear (inverted U-shape). Then, for example, an executive with $30 \%$ equity in the firm, whose other family members own 35\%, will regard $65 \%$ rather than $35 \%$ as the relevant percentage. This may induce him to select a small bonus (say, the optimal behavior for 65\%), rather than reap money from the firm in the form of a large bonus (say, the optimal behavior for 35\%). That is, the sum of the share holdings of the executive and the rest of the family should enter in the explanation, rather than the holdings of the rest of the family per se, where holdings of other family members (brothers, sisters, parents) substitute for executive holdings, both in terms of power and in terms of the objective being maximized.

\footnotetext{
2 Nevertheless, several studies (e.g., Altonji, 1992) find that individuals are not completely altruistic towards family members.
} 
$\mathrm{H}_{1.2}$ : Bonus (and salary) and equity holdings of CEO and his family are curvilinearly (inverted U-shape) related.

Over time, top executives will also accumulate social capital with other incumbent executives and directors of the firm, typically starting with small gifts, with the magnitude of gifts gradually increasing over time (Homans, 1961; Blau, 1964). Earlier we indicated that tenure is associated with increased embeddedness, including more dense social exchange relationships with elaborate and diffuse patterns of obligations among the members of the top management team, centrality in the communication network, institutionalization of governance arrangements that reflect the CEO's preferences. The top executive is also instrumental in screening and hiring new executives and directors, and in setting their compensation (Tosi and Gomez-Media, 1989; Wade et al., 1990; Singh and Harianto, 1989). His social surroundings will be particularly prone to mirro his stamp when his tenure is comparatively long. Share holdings endow the executive with additional, formal power in this respect, and additional opportunities for "gift giving" to other executives and directors, with perhaps as the biggest gift, to form some mentorprotégé relationship that leads to the latter's promotion into the ranks of senior management (compare Kanter, 1977). When the top executive's tenure increases, the indebtedness that he creates through his holdings is expected to increase, both towards executives that have been there from the start, and even more so towards executives and directors nominated after - and by - the executive. From a social exchange perspective, this will result in larger return gifts, also in situations where share ownership per se is irrelevant, such as in compensation committees.

Finkelstein and Hambrick (1989) documented a curvilinear relation (inverted Ushape) between tenure and pay, which in itself is consistent with our power-derived interpretation. However, their evidence is also consistent with a life cycle-argument. The implication is that tenure interacts with CEO equity holdings in determining the size of CEO bonus and salary, with the presumption that tenure is a proxy of covert power. Our argument regarding power in shaping executive pay implies, therefore, that the effect of 
equity holdings will be moderated by the tenure of the senior executive. The tenure's effect may either increase over the whole tenure period (if executives with share holdings become more influential and more successful in manipulating their pay), or the effect might in fact decline with increased levels of tenure (if the executive eventually becomes a figurehead with one or two younger executives emerging as the new and comparatively more powerful successor). This leads to the following hypothesis:

$\mathrm{H}_{2}$ : The effect of equity holdings on executive pay is contingent upon CEO tenure.

Anecdotal evidence suggests that top executives who were present at the time of founding wield more power than can be explained by their tenure and share holdings alone. For example, the quote at the beginning of this paper from Smith (1990) suggests that founders can still be very powerful, even when relatively small holdings remain. In young firms, the social arrangements are still informal and fluid and any one of the top management team enjoys some latitude to build a basis of power. In the extreme case, when the CEO is the founder, he enjoys first mover advantages and can maneuver subsequent recruits into a position of dependency and mentoring. The CEO as founder is therefore likly to have surrounded himself with people who are obligated to him. Furthermore, he will probably have expert knowledge of the technology of the business he started. The reputation effects of founder confer the undisputed legitimacy to set precedents and to shape the norms by which decisions are made. The CEO as founder is therefore likely to control information and implicit knowledge as important sources of informal power. A top executive who inherited share holdings and gradually grew into the firm will likely have less power, particularly when the firm matured and became more mechanistic. This leads to the following hypothesis:

$\mathrm{H}_{3}$ : In start-ups and comparatively young firms, CEOs are more successful in leveraging their holdings to manipulate the size of their bonuses.

Top executives may not only derive power from their embeddedness in a network of relationships with relatives, directors, executives, suppliers and customers. They may also enjoy superior information on relevant decision issues, including factors which affect 
their own performance. Our fourth hypothesis on bonuses bears on such power engendering information asymmetries, and how they relate to firm diversity.

Various authors have studied the relationship between corporate diversity and executive pay. The combined theory and evidence suggests a non-linear relationship. In single business firms, the task of the CEO is relatively simple. In that case, he has only one unit to supervise, and the strategic question of what business to be in, is less relevant. Thus, it is relatively easy for the board to assess CEO performance (Balkin and GomezMejia, 1990; Gomez-Mejia, 1992). When moving from single business firms to the more diversified firms but still remaining within Rumelt's (1974) categories of dominant- and related-product firms, the task of top executives becomes more complex. Under such ambiguous conditions, there exist more latitude for power plays and payment of side payments. The CEO might therefore discover more opportunities for manipulating his pay. Particularly with division heads, one would expect more opportunities for corruptive practices (Eccles, 1988); the CEO is closely involved in monitoring SBU executives and in preserving economies of scope among the portfolio of businesses, to foster spill-over of knowledge and coordination of complementary assets (Lorsch and Allen, 1973; Balkin and Gomez-Mejia, 1990; Gomez-Mejia, 1992). Such conditions are absent in highly diversified firms, where the task of the top executive becomes less complex again. SBUs are relatively autonomous and self-contained. It is not necessary for top executives to exploit synergies, and monitoring of SBU executives on synergistic criteria becomes moot. Instead, SBU executives are paid based on the performance of their SBU (Berg, 1969, 1973). Moreover, the pay structure of top executives is relatively formal and based more on objective criteria, such as divisional performance (Salter, 1973; Galbraith and Nathanson, 1978; Gomez-Mejia, 1992).

It is also of interest to note that several studies have take measures of strategic diversity as proxies of managerial discretion, and by implication the potential to accumulate covert power. A recent paper (Worrell, Nemec and Davidson, 1997) considers international diversification and broadening of the client base among financial institutions as an indication for discretion, with the assumption that the 
performance-compensation relationship should be stronger among diversified banks. In the present paper, however, we assume that CEOs can manipulate their compensation package whenever they manage under conditions of high discretion, all this due to information benefits they enjoy vis a vis other stakeholders.

The combined literature suggests that job complexity for top executives, and the concomitant information asymmetry between boards and top executives regarding the latter's performance, is largest at intermediate levels of diversity. More information asymmetry implies more hidden power for top executives (Aram and Cowen, 1983). Thus, we expect top executives with shares in intermediately diversified firms, to be more successful in manipulating their pay than executives in firms at either of the extremes, where they enjoy diminished discretion. Consistent with our prediction, Napier and Smith (1987) found higher bonuses for corporate executives at intermediate levels, but other studies (e.g., Gomez-Mejia, 1992) suggested lower bonuses. In fact, the relation between diversity and bonuses may be affected by many other factors than power. For example, if information that principals have about the performance of top executives as agents is "noisier" at intermediate levels of diversity, agency theory predicts that this leads to lower optimal bonuses. Also, if job complexity for top executives is relatively high at intermediate levels, and executives have a large impact on firm value (since they have a strong power on SBUs and their synergies), a marginal product interpretation suggests higher optimal bonuses. It is difficult to control for these other effects of diversity on bonuses when testing our power interpretation. Therefore, we will test an hypothesis that more directly bears on the role of power in shaping CEO compensation. Our interpretation implies that even if (absolute) bonuses would be lower at medium levels of diversity, the magnitude (per dollar) of the bonus due to share holdings is higher than at either of the extremes. This leads to the following hypothesis:

$\mathrm{H}_{5}$ : The effect of equity holdings on CEO pay is contingent upon the degree of firm diversification, with pay being higher at immediate levels of diversification. 
Finally, it should be pointed out that the above hypotheses stand in sharp conflict with the major tenets of agency theory. There is a vast body of research on CEO compensation that disregards the power of the senior executive. Rather, it postulates that compensation is a function of corporate performance whenever the remunerative regime molds CEO decision making toward the needs of the firm and its owners.

Many studies in financial economics have indeed documented a positive relationship between executive compensation and firm performance (Lewellen and Huntsman, 1971; Larcker, 1983; Murphy, 1985, 1986; Coughlan and Schmidt, 1985; Jensen and Murphy, 1990). However, Bettis and Kerr (1985) found no such relation. Financial economists maintain that stock market performance is the correct benchmark, but empirical studies suggest that accounting performance is more common. For example, Jensen and Murphy (1990) found that the firm's stock market performance explains only 0.008 of the variance of CEO pay (salary and bonus). The addition of accounting performance to their model increases the explained variance to 0.045. We expect accounting performance to be particularly relevant in non-listed firms, where market-derived proxies of performance are not available. In line with our earlier remarks, emphasizing that salaries are intended to compensate executives for job complexity, and bonuses for annual performance, we hypothesize:

$\mathrm{H}_{5}$ : The executive's bonus rather than his salary is tied to the firm's accounting based performance indices.

\section{Method}

\section{Sample}

The data are from a 1985 Dutch sample of top executives, recently made available by the HAY Management Consulting Group. Information on ownership, compensation, power, and firm attributes came from a survey among randomly selected executives 
(mostly executive board members) in mid-sized, non-listed firms in a wide variety of industries.

Issues of non-US type data require us to ask whether the findings are idiosyncratic to a particular setting. Since the firms were privately held, they are comparatively immune to the market for corporate control. In fact they are comparable to US data files on firms with poison pills (Malatesta and Walkling, 1988; Ryngaert, 1988), to firms that underwent an LBO (Kaplan 1989; Smith, 1989), and to other non-listed firms. Finkelstein and Hambrick (1989) argue that their evidence from the leisure industry may be biased due to idiosyncratic labor market conditions and ownership structures. The present study reduces this problem by analyzing multiple industry data on chemical firms, textiles, construction, electro-technical firms, furniture, food, coatings, and so on.

For obvious reasons, we only selected independent firms from the HAY sample (subsidiaries were omitted). Also, we only selected data on executive board members. Finkelstein (1992) argues that the choice of the unit of analysis in research on top executives and the issue of executive power are two sides of the same coin. His empirical research shows that power in corporations is not restricted to CEOs. This is a fortiori true in the Netherlands, where decision making is done collectively rather than by a single actor such as the CEO (Hofstede, 1980; Pennings, 1993). Therefore we selected data on all executive board members.

In terms of firm size, the data set is already homogenous to some degree, since the data concern executives of mid-sized firms. Nevertheless, a top executive of a firm of, for example, 1000 employees cannot readily be compared to a "top executive" of a firm of 10 employees. Therefore, all executives of firms with less than 50 employees were omitted from the data set. We selected all executive board members of the remaining firms $(n=164)$. Because of missing data, 21 observations were removed from the sample, leaving 143 executives. A chi-square analysis showed that the omitted cases did not differ significantly from the remaining sample in terms of executive characteristics (shareholdings, bonus, salary, tenure) and firm 
characteristics (sales, employees, diversity). Thus, we do not believe that the remaining sample is seriously skewed in the direction of the hypothesis testing. The mean sales of the remaining firms were fl. 292 million (one guilder is roughly \$ .65), and the mean number of employees was 638. Therefore, these firms are somewhat smaller than the firms that are generally analyzed in the compensation literature.

Finally, it should be pointed out that in the Netherlands the top management team and the board of directors are two distinct entities between which there cannot be overlapping membership. This strengthens the notion of the board of directors as the principal in that its members represent the residual claimants, and the executive board as the agent. It also implies that agency and power problems that result from having insiders on the board (Singh and Harianto, 1989; Finkelstein and Hambrick, 1989; Wade et al., 1990; Byrd and Hickman, 1992), and in particular, from CEO duality (the CEO is also the Chairman, see Boyd, 1994) do not exist in the Netherlands. Exhibit A provides a listing of the variables that are used in predicting CEO base pay and bonus.

--Exhibit A about here --

\section{Measures}

BONUS is the total 1984 bonus of the executive, dependent on firm performance, individual performance measures, etc. SALARY is the 1984 salary. BONUS and SALARY are in Dutch guilders (one guilder is roughly \$ 0.65). SHARE is the fraction of shares held by the executive, and SHAREFAM is the fraction of shares held by the executive's family (executive, spouse, children, parents, brothers and sisters). FIRMYEAR is the number of years of firm tenure. MARKETS is the number of markets in which the firm was active (as reported by the executive).

The HAY data set did not contain direct information on whether the top manager was the founder. Instead, the data set contained information regarding the age of the firm, measured on an ordinal scale, with scores 1 ( $<2$ years), 2 (2-5 years), 
3 (5-10 years), 4 (10-25 years) and 5 (>25 years). Category 5, representing firms older than 25 years, was the most frequent (79\% of firms). We combined this information with the firm tenure of the manager. For example, if the manager had had firm tenure for 7 years and the variable firm age had any other value than 3 (5-10 years), the manager could not possibly be the founder, and his score on the newly created variable FOUNDER became 0, else 1. Similarly, if he had had firm tenure for 21 years and the age of the firm had any other value than 4 (10-25 years), his score on the variable FOUNDER became 0, else 1. Clearly, the variable FOUNDER contains some noise. All managers with score 0 cannot possibly be founders. All founders will have a score of 1 . However, some managers with score 1 may not be founders, since having had tenure (almost) from the beginning of the firm does not guarantee that the manager founded the firm as well. Therefore, the measure will likely contain some noise. Of course, noisy measurement is the rule, rather than the exception in empirical research. Nevertheless, any effect associated with FOUNDER estimated in this study may underestimate the "true" effect associated with being a founder, and any failure to reject the null hypothesis (no effect associated with FOUNDER - main effects, or interaction terms including this variable) should be interpreted with some care.

SALES and EMPLOYEES are the 1984 sales and number of employees (full time equivalents) of the firm. Like most previous compensation studies, we used the $\log$ of these variables. The data set also allowed us to calculate the profit per employee for each firm. This variable reflects the ultimate performance measure for top executives, whose main task according to agency theory is to screen and possibly ratify proposals from lower level executives, and to monitor their performance (Fama and Jensen, 1983). The profit per employee may differ across industries, reflecting differences in risk and thus in risk premium commanded by suppliers of capital, differences in capital intensity, etc. To mitigate potential confounding industry-effects, we calculated the deviation of the profit per employee from its 1984 industry average, divided by the 1984 industry average. This leads to the variable 
PPE, the percentage that the profit per employee is above or below the industry average.

\section{Results}

Table 1 presents the means and standard deviations, together with the correlation matrix pertaining to the variables used in the testing of hypotheses. The table shows that equity holdings do not correlate significantly with salary and bonus.

--please insert table 1 here--

The questionnaire that was part of HAY's 1985 compensation survey also contained a variable that allowed some first insight regarding the power associated with the observables in our study. The item was:

The discretion I have to implement changes or innovations in the firm is, in general:....

where managers were requested to score from 1 (very small) up to 7 (very large). Note that a recent study (SMJ, 1997) treats “discretion” as an attribute that either accentuates and amplifies or attenuates the performance - compensation relationship. The correlations of this item with the variables SHARE and SHAREFAM were 0.27 ( $p<0.01)$ and $0.22(p<0.01)$, respectively. None of the correlations of the item with the variables FIRMYEAR, FOUNDER, and MARKETS were significant in the expected direction. The correlations of the item with BONUS and SALARY were $0.14(\mathrm{p}<0.10)$ and 0.07, respectively. Even the significant correlations with this simple and general measure of managerial power are quite low, but they form some first indication that (c)overt power is related to share holdings (by the manager and 
his family) and to compensation (in particular, the manager's bonus), rather than to the variables FIRMYEAR, FOUNDER, and MARKETS.

We now continue with testing the hypotheses of this paper. We hypothesized that the relationship between equity holdings and compensation are contingent on tenure. Previous studies have found mixed results on the relation between tenure and pay. Our theory is silent on the precise functional form, in the sense that it does not discriminate between power monotonically increasing in tenure, and power first increasing and then decreasing. From the perspective of our theory, the precise functional form is an empirical matter. To gain more insight in this respect, we estimated the following equation for various levels of FIRMYEAR, where $\$ 1$ reflects the estimated effect of equity holdings on bonus:

BONUS $=ß 0+\beta 1$. SHARE + 2. SHARE2 + 3 .MARKETS + 4 .FOUNDER + ß5.SALES +ß6.EMPLOYEES + ß7.PPE + e

Obviously, the size of the subsets on which this model is estimated must at least equal the number of parameters to be estimated. But too small subsets will likely lead to wild variations in estimates of $ß 1$, blurring the view on the underlying pattern. Nevertheless, we would like as many estimation points as possible to be able to identify a pattern at all, e.g., to identify inflection points in case of non-linearity. The results are plotted in figure 1 . The plot is a "moving-average" analogy, where each point reflects the estimate of $ß 1$ for the corresponding point on the $\mathrm{x}$-axis and the three preceding points, weighted according to the number of observations for each point. Thus, an observed increase in the figure in $§ 1$ from $x i$ to $x i+1$ reflects the additional contribution of $x i+1$ to the estimated sensitivity. This results in a relatively fine-grained picture of the trend, while extreme fluctuations are dampened.

--please insert figure 1 about here -- 
Figure 1 shows a non-linear pattern, with seniority at 20-30 years of tenure showing higher bonus pay-outs than seniority at higher and lower levels. Subsequent econometric analysis, using Cook's test, showed that estimates in the 20-30 tenure range differed significantly (upwards) from a line fitted through all points in figure 1, as did estimates in the $>30$ tenure range (downwards). We modeled this pattern in the simplest possible way, with a dummy D1, valued 1 if the executive had 20-30 years of tenure, and 0 otherwise. Of course, some information is discarded when continuous scales are converted into dummy variables. There are more complicated ways to model pay-power relationships. However, if the power-effect is sufficiently strong, we should find significant effects in our subsequent analysis regardless of whether more information could be extracted to expose the relationship.

Earlier, we hypothesized a non-linear effect of holdings on CEO pay for various levels of diversity. To get more insight in this relationship, we followed a similar procedure with respect to the variable MARKETS (of course, now the variable MARKETS in model (1) replaced by FIRMYEAR). The result is presented in figure 2.

-- please insert figure 2 about here --

Consistent with expectations, visual inspection suggests increased sensitivity of bonuses for share holdings for intermediate levels of diversity, in the range of 10-20 markets. This intuition is further supported by Cook's test, that showed that estimates in the 10-20 market range differ significantly (upwards) from a line fitted through all points in figure 2, as did estimates in the > 20 tenure range (downwards). Analogously, we operationalized this pattern with a dummy $\underline{\mathrm{D} 2}$, valued 1 if the number of markets was in the 10-20 range, and 0 otherwise.

\section{Tests of the hypotheses on bonus data}


Table 2 presents evidence on the hypotheses on bonuses. Model 1 captures the impact of the power variables (FOUNDER, D1, D2), size variables (SALES, EMPLOYEES), and the observables (FIRMYEAR, MARKETS and PPE). This model will be used as a benchmark, to assess the explained variance of other models that also include shareholdings.

--please insert table 2 about here--

The most significant effect in column 1 is the effect of PPE ( $<<0.001$, one-sided test). This corroborates $\mathrm{H} 5$, that the bonus of executives is tied to the firm's accounting performance. The adjusted R2 of this model is 0.064 . This is of the same order of magnitude as in earlier studies, e.g. Jensen and Murphy (1990) find an explained variance of 0.045 (unadjusted) in their model containing accounting performance.

Model 2 extends this model with the executive's holdings. The evidence corroborates the predicted curvilinear relation (inverted U-shape) between bonuses and shareholdings (H1.1). The effect associated with SHARE is positive and significant ( $\mathrm{p}<0.05)$, and the effect associated with SHARE2 is negative and significant (p $<0.10)$. Thus, it seems that, on average, shareholdings are indeed used to manipulate top management bonuses. These findings differ from Finkelstein and Hambrick (1989) who found no support for the predicted curvilinear relation. The adjusted R2 increases from 0.064 to 0.078 .

In column 3, the executive's holdings are substituted for family holdings (including the executive's holdings). Consistent with H1.2, SHAREFAM has a significant positive effect and SHAREFAM2 has a significant negative effect. In fact, the effects are more significant than the effects in column 2 regarding the executive's holdings. These results differ from Finkelstein and Hambrick (1989), who found no support for their hypothesis on the impact of the holdings of the family (excluding the 
executive) on the executive's bonus. As an additional test, we also regressed BONUS on (SHARE-SHAREFAM) and (SHARE-SHAREFAM)2, using a formulation very similar to Finkelstein and Hambrick's model. We found no support for this model, suggesting that the contradictory results in Finkelstein and Hambrick's study on family holdings were at least to some extent caused by their model formulation, and not (only) by the idiosyncratic nature of their data.

Column 4 presents the results regarding our hypotheses on the mechanism of the executive's power from shareholdings: through their tenure (H2), level of firm diversity (H3), and foundership (H4). All interaction effects have the expected sign and are highly significant $(\mathrm{p}<0.01)$. The main effect associated with SHARE becomes insignificant. These results strongly corroborate a key notion of this paper, that power from share holdings is conditional on whether it is backed up by other sources of covert power. The estimates imply, for example, that an executive with average holdings (10\%, see table 1$)$ that is also in the 10 -20 years of tenure range has a bonus that is $\mathrm{f} 14,499$ higher than of other executives. If, in addition, he is employed at a firm that is intermediately diversified, the bonus is still f 19,951 higher. These amounts are non-trivial in view of the average bonus of $f 33,024$. The relation between bonuses and firm performance (PPE) remains significant. The associate coefficient implies, for example, that a top executive in a firm that is twice as profitable as the industry average, earns a bonus that is $f$ 18,327 higher. The explained variance (adjusted) of this model is 0.142 . The inclusion of share holdings (main effects and interactions) more than doubles the explained variance, compared to the benchmark model that only contained performance.

We conducted several tests for robustness of the results. All estimation results were reproduced with the PPE measure replaced by PPS, the percentage that the profit per sales were above industry average. The results were almost identical to table 2, except that the effects from PPS were somewhat less significant $(\mathrm{p}<0.05)$ than the effects from PPE $(p<0.001)$. This is consistent with the agency theory notion that the main task of top executives is to enhance the productivity of lower level executives 
and workers (through screening proposals and monitoring their behavior) as their benchmark, rather than profit per sales. Finally, our analysis utilized multiple industry data to reduce potentially disturbing industry-effects. In theory, industry specific distortions cannot be excluded even in case of multiple industry data (see e.g., Rumelt, 1982), and even though we corrected profitability for industry specific power. Therefore, we reestimated all models, using BONUS* and SALARY* (the deviations of the manager's bonus and salary from the industry average) as independent variables, instead of BONUS and SALARY. The estimation results were very similar to the results in tables 2 and 3 (if anything, somewhat more supportive).

\section{Tests of the hypotheses on salary data:}

Table 3 presents tests of the hypotheses on salary data. All three coefficients in column 1 operationalizing firm complexity, SALES, EMPLOYEES, and d2, have the expected sign and are significant. This model explains 0.452 of the variance (adjusted) of salary. If we hold hypothesis 5 to be the "base line" test, it is clear that no significant relation is measured with firm performance.

--please insert table 3 about here--

Columns 2 and 3 extend this model with the executive's holdings and family holdings. The effects associated with both types of holdings are significant, which further corroborates H1.1 and H1.2. Finally, all three interaction effects associated with share holdings in column 4 have the expected sign, while 2 out of three are significant. These results lend further support to $\mathrm{H} 2-\mathrm{H} 4$. The interaction term associated with intermediate levels of diversity is not significant. It seems that executives in such firms get higher salaries anyway, due to their higher job complexity (the effect associated with d2 remains 
significant). Similar tests for robustness, as in the case of bonuses, did not lead to different conclusions.

\section{DISCUSSION AND CONCLUSION}

\section{Ownership and control}

This paper adds to the literature on ownership and control by exploring a potential paradox associated with top manager share holdings. Classical agency theory maintains that incentives are optimal when the manager is the full owner of the firm (Jensen and Meckling, 1976). However, executives may use the power associated with their holdings to shield themselves from hostile takeovers or other disciplinary actions of external investors (Morck, Sleifer and Vishny, 1988; McConnell and Servaes, 1989). In theory, executives may use their equity holdings to perpetuate sub-optimal levels of skills and effort; maintain a larger staff, office building, company car, or jet than is economically efficient; or manipulate their salary and other pay elements. Our paper explored whether such political exercise of power does indeed occur, focusing on the manager's pay. We analyzed data on non-listed firms, where hostile takeovers are unlikely to happen. We found that top managers of these firms do indeed use family holdings (owned by themselves or relatives) to manipulate their salary and bonus.

We also peeked into the black box of power associated with share holdings by injecting proxies of informal power. Our results showed that formal power from internal holdings is not sufficient for managers to manipulate their pay. Rather, it is a more subtle process, where the power from their holdings depends on their "embeddedness" in the firm, i.e., whether they can back up the overt power from their holdings with other more furtive sources of power. We investigated two sources: power rooted in social exchange contracts (proxied by whether the manager founded the firm, and by his tenure), and power rooted in information asymmetry vs. the board of directors (proxied by the degree of diversification of the firm). We hold these 
conditions to be major opportunities for power creation. They are often hidden behind the overt manifestations of power, including formal position of CEO. Being the founder, and/or accumulating tenure creates ample opportunities for institutionalizing governance practices, establishing communication networks, and solidifying exchange relationships. The CEO surrounds himself with people who owe him obligations and which become manifest in the way the former can shape decisions that protect his personal interest. Consistent with predictions, we found that top managers manipulate their salaries and bonuses, if the formal power from their holdings is backed up by these sources of power.

Our results do not imply that social exchange contracts per se are bad for investors. Managers and directors may develop social exchange contracts over time, where directors "give" trust, loyalty, recognition, perhaps even compensation to top managers, and managers "give" work effort in return (cf. Homans, 1961, Blau, 1964). We might in fact have encountered these beneficial effects in our study. If top managers are disciplined by social exchange contracts (their strength being proxied by foundership and tenure), and if more work effort leads to higher return gifts in the form of salaries and bonuses, than tenure, and being a founder. ${ }^{1}$ However, no significant "main" effects of tenure and foundership on bonuses and salaries were found in our study. Alternatively, we found strong interaction effects between manager holdings and other sources of power, regarding their salaries and bonuses. This was consistent with the theory that top managers use the power rooted in their social exchange contracts and in information asymmetry versus the board of directors, to magnify the formal power from their holdings, in order to manipulate their bonuses and salaries.

1. There is also another story that could have rationalized observed correlations between these variables - if directors learn about the manager's ability and effort through time (reducing the information asymmetry in this respect) and substitute bonuses for salaries in compensating the manager (Murphy, 1986). 


\section{Compensation schemes from an agency perspective}

The present study, and, in particular hypothesis 5 , adds also to the agency literature on compensation. These studies - typically analyzing data on top managers of Fortune top 500 firms - find significant relationships between top manager bonuses and firm performance (e.g., Murphy, 1985; Benston, 1985; Jensen and Murphy, 1990). Our results reveal the same 'stylized fact' for non-listed, relatively small firms, with a wide variety in internal ownership. Thus, our study extends the domain of firms for which the stylized fact applies.

The results in this paper are also helpful in rationalizing two other 'stylized facts' that are anomalous, or puzzling, for agency theory. Agency theory suggests that variable pay and equity holdings are used as complementary sources of pecuniary incentives, where their relative importance varies across firms and industries, depending on relative costs and gains (Lambert and Larcker, 1987). It is puzzling for agency researchers that previous empirical studies do not corroborate the predicted negative correlation between bonuses and equity holdings (Benston, 1985; Jensen and Murphy, 1990). However, suppose that top managers use their holdings to manipulate their pay, rather than that the incentive mix is designed by an omnipotent board of directors. Then it is not surprising that the negative relationship between equity holdings and bonuses predicted by agency theory is not observed.

A second puzzle is as follows. Agency theorists traditionally maintain that executive pay is strongly tied to performance, provided executives are bound by a well designed compensation plan. However, Jensen and Murphy (1990) find that the observed relationship between top management pay and performance is too weak to be consistent with principal-agent theory (see also Warner, Watts and Wruck, 1988; Weisbach, 1988; Gilson, 1989). Various studies in the management literature, and more recently in agency theory, have suggested explanations of why pay is weakly tied to performance, including measurement problems, reduction of intrinsic drives through external rewards, executives focusing too narrowly on the objectives in their 
compensation contracts, the absence of external blockholders, and the public outcry over large bonuses for top managers (Deci, 1975; Baker et al., 1988; Gomez-Mejia and Balkin, 1992; Baker; 1992; Frey, 1992, 1993; Tosi and Gomez-Mejia, 1989, 1994; Singh and Harianto, 1989; Jensen and Murphy, 1990). Based on the results of our study, we propose an additional story that can - partially - explain weak payperformance relationships: that top managers use their equity holdings to manipulate their pay, thus distorting pay-performance relationships.

\section{Compensation and corporate governance}

Our paper is primarily concerned with the newly emerging tradition in the management literature that considers political factors key determinants of executive pay (Singh and Harianto, 1989; Wade et al., 1990; Tosi and Gomez-Mejia, 1989, 1994). Previous studies typically compared top management pay in 'externally controlled' firms (where external blockholders are present), with 'management controlled' firms (where the shares are dispersed among many external parties). Our paper complements this research by analyzing the third type of firm distinguished by McEachern (1975): 'owner managed' firms. Our study adds to this literature by showing that managers use power associated with their equity holdings to manipulate their pay, if this power is embedded in other sources of informal power (e.g., tenure or information asymmetry).

We also found, consistent with earlier studies, that salaries are largely driven by job complexity (proxied in this study by the number of employees, firm sales, and firm diversity). In addition, we found that top managers use their holdings to determine their salaries, although this effect was smaller than the impact of job complexity on salary. A related conclusion is that our results generally suggest that bonuses and salaries are different from the perspective of the principal - salaries compensate the manager for job complexity, bonuses for performance - but similar from the perspective of the receiving manager, that seeks to impact both pay elements through his equity holdings. 


\section{Suggestions for further research}

Our results showed that top managers use the power from their "residual claims" to take a cut from the residue before sharing the remainder with other residual claimants. (A parallel conclusion was that when approaching full ownership, the manager's propensity to increase his pay diminished). Future studies may provide more insight into whether managers use their holdings for other political purposes as well: to maintain a larger staff, office building, company car or jet than is economically efficient, etc. Future studies may also peek deeper into the black box of internal control through internal ownership. Future research on the weaknesses of internal ownership would complement existing research emphasizing the strengths of ownership as a control system in terms of manager incentives, and the weaknesses of internal control by the board of directors (for an overview, see Jensen, 1993). Eventually, this may lead to a more balanced view on both the strengths and weaknesses of the two control systems. More insight into these weaknesses may also lead to improvements in how internal control systems in corporations work, increasing the efficiency of firms, and at a more aggregate level, of the economy.

A particularly interesting research object in this context is the LBO (see also Smith, 1989; Kaplan, 1988, 1989; Jensen, 1993). In theory, LBOs have similar benefits as other owner managed firms but may avoid (some of) the efficiency costs. A small number of professional investors typically own $60 \%$. Before they participate in the buyout, they will likely have screened incumbent management intensively (regarding sub-optimal levels of skills, etc.). After the buyout, they engage in intensive monitoring. Lenders are also motivated to monitor the firm, due to the high debt load of the firm and the high probability of bankruptcy. The joint monitoring by external blockholders and lenders may keep manager-owners from political "games", to serve their own interests at the expense of external parties, at least in the first years after the buyout. After some time, the manager-owner may become more entrenched, lenders will become less active because the firm has paid off portions of the initial 
high debt load, and initial investors may have diluted their holdings to cash in on their capital gains. In sum: the firm starts to resemble other owner-managed firms. This story suggests that LBOs are optimal only temporarily, vis-a-vis control by the board of directors, and that LBO firms go back to "normal" again after the restructuring that inspired the LBO has been completed. Consistent with this view, Kaplan (1989) finds that LBOs typically "survive" 5-7 years before going public again. Future studies may provide more insight here.

Finally, various writers (Hofstede, 1983; Pennings, 1993) have suggested that empirical results on compensation schemes are idiosyncratic to the particular institutional and cultural setting of the firms in the data set. This also applies to our results from the Dutch setting. We nevertheless found that top management pay was tied to performance, a result previously found in studies analyzing data from AngloSaxon settings. This 'stylized fact' consistent with agency theory was replicated despite the fact that the (non-listed) firms in our sample were subject to less discipline from the market for corporate control than the firms in most previous studies, and that, on average, principals in the Netherlands perceive strong pay-for-performance relationships as less important than principals in the US (Pennings, 1993). Furthermore, there is no reason to believe that executives in other countries, under similar ownership arrangements would not be motivated to manipulate their pay if they have the leverage to do so. Obviously more research is required to fully sustain this claim.

\title{
Additional references
}

\author{
Blau, P.M.
}

1964 Exchange and Power in Social Life, New York: Wiley.

Hickson, D.J., Hinings, C.R., Lee, C. A., Schneck, R.E., and Pennings, J.M. 
1971, A strategic contingencies' theory of intraorganizational power, Administrative Science Quarterly, 16, 216-229.

French, J.P.R. and Raven, B, 1959 The bases of social power. In D. Cartwright (ed.), Studies in Social Power: 150-167. Ann Arbor: University of Michigan.

Krackhard, David

1991 Assesing the political landscape: structure, cognition and power in organizations. Administrative Science Quarterly, 35, 342-369.

Pfeffer, Jeffrey

1992 Managing with Power. Boston: Harvard Business School Press.

Pfeffer, Jeffrey \& Konrad, Allsion

1991 The effect of individual power on earnings. Work and Occupations

Worrell, D. L.; Nemec, C.; Davidson, W. N., 1997, One Hat Too Many: Key Executive Plurality and Shareholder Wealth, Strategic Management Journal, 18, 7, pp. 499-507 